\title{
Engine Misfire and Knocking Detection on Vehicle Using Closed Loop System
}

\author{
Ajmir bin Mohd Saill, Mohammad Nazir Abdullah, Elmi Abu Bakar, \\ Muhammad Nabil Asyraf bin Jafri
}

\begin{abstract}
Air pollutant to environment is the major issue due to gas emission from industries and vehicles. The source from the vehicle are misfire condition and worse knocking condition will affect the engine. It cause by several components failure such as clogged spark plugs and high voltage cables, insufficient intake mixture, and others. A study is presented of the influence of using a microcontroller to actuate artificial engine misfire and knocking condition on a spark ignition engine. Single cylinder engine is use in the study. The paper focuses on detection of engine misfire and knocking (EMK) by actuating the artificial condition of EMK. Microcontroller is design to initiate spark plug ignition timing by several times, so the signals can be identifies for the fault detection. A switch will be controlling the artificial misfire and knocking condition. Therefore the switch for artificial EMK condition is located with the same controller. The accelerometer mounted on the engine signal and it will record during the artificial EMK condition is activated for analysis.
\end{abstract}

Index Terms-misfire, knocking, accelerometer

\section{INTRODUCTION}

In the past decades automobile industries show a rapid growth of technological advancement. The major issues within the growth such as engine misfire and knocking(EMK) that effected the environment and health[1]. Research has been made to identify these phenomena and fast detection methods are design to overcome the situation.

However, the engine condition and maintenance made by user will affect the condition toward the EMK condition[2]. Gas emission is the major concern. The engine will combust uncertain mixed air fuel, will caused pollution. Ignition timing will play the major role for the engine running smoothly. Reference [1][3] stressed out components lead to ignition timing such as ignition coil, intake sensors, spark plugs and engine leaks should be restore in good condition to avoid EMK. engines speed increases from low to high speed without combusted knock at surface running condition [4].

There different effects of combustion by using different type of fuel. Combusted knocks occurs in different speed and

Revised Version Manuscript Received on 10, September 2019.

Ajmir bin Mohd Saill, School of Aerospace Engineering, Engineering Campus, Universiti Sains Malaysia, 14300 Nibong Tebal, Penang, Malaysia E-Mail: ajmir @ yahoo.com

Mohammad Nazir Abdullah, School of Electrical and Electronic Engineering, Engineering Campus, Universiti Sains Malaysia, 14300 Nibong Tebal, Penang, Malaysia eemnazir@usm.my

Elmi Abu Bakar, School of Aerospace Engineering, Engineering Campus, Universiti Sains Malaysia, 14300 Nibong Tebal, Penang, Malaysia meelmi@usm.my

Muhammad Nabil Asyraf bin Jafri, School of Mechanical Engineering, Engineering Campus, Universiti Sains Malaysia, 14300 Nibong Tebal, Penang, Malaysia nabilasyraf95@gmail.com ignition timing. What we know about knock is largely based on case studies undertaken in fuel octane number. Reference [5] research on combustion knock occurs with non-auto-ignited combustion at 900rpm. Whereas, others research identified combustion knock at $1200 \mathrm{rpm}$. It has been assumed that engines speed increases from low to high speed without combusted knock at surface running condition [4].

Results from earlier studies demonstrate a strong and consistent association between natural gas (NG) and diesel for the use of ignition spark engine (IS). Reference [6] shows how, in the past, research into NG was mainly concerned with ignition delay. $\mathrm{NG}$ took a longer duration time of combustion and a slower burning rate. Refer to table 1 , at $0 \% \mathrm{H} 2,100 \%$ 2500rpm, it shows that ignition timing is 31.2 degree, whereas at $1750 \mathrm{rpm}$ increase to 32.4 degree and at $1000 \mathrm{rpm}$ decrease to 30.6 degree

Table 1 Tests conditions[6].

\begin{tabular}{llllll} 
\% H2 & $\%$ & NG Engine speed (rpm) & $\begin{array}{l}\text { Ignition timing } \\
\text { (crank angle before }\end{array}$ \\
\hline \multicolumn{1}{l}{ TDC) } & & & & \\
\hline 0 & 100 & 2500 & 31.2 & \\
25 & 75 & 2500 & 28.8 \\
50 & 50 & 2500 & 24.6 \\
75 & 25 & 2500 & 20.4 \\
100 & 0 & 2500 & 12 \\
0 & 100 & 1750 & 32.4 \\
25 & 75 & 1750 & 28.2 \\
50 & 50 & 1750 & 25.8 \\
75 & 25 & 1750 & 18 \\
100 & 0 & 1750 & 9.6 \\
0 & 100 & 1000 & 30.6 \\
25 & 75 & 1000 & 24.6 \\
50 & 50 & 1000 & 21.6 \\
75 & 25 & 1000 & 16.2 \\
100 & 0 & 1000 & 5.4
\end{tabular}

Identifying the optimal spark timing must be determine by the fuel, air fuel ratio, cylinder pressure and engine speed [7].

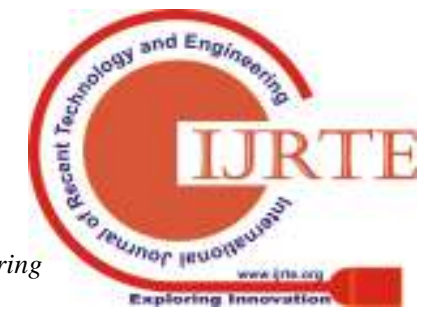


Where the important of identifying the optimal spark timing may lead to maximum engine performance [8].

Fuel injection are used widely in IC engines. The fuel could be control wisely to get different effect of performance and decrease gas emission in different manner. [9] experimenting on the injection flow rate and spray pattern. [10] suggested in different perspectives of fuel injection by increase of injection spray length. Table 2 shows similarity result by controlling the flow rate and spray pattern compare to controlling injection spray length. By getting the exact timing of injection would able increase the engine performance and lower the gas emission. The spark plug plays another role to burn the entire air fuel ration in the combustion chamber. By expanding the flame length, it will make the air fuel ratio burn completely [11].

Table 2, Different results of fuel injection experiment.

\begin{tabular}{|l|l|}
\hline $\begin{array}{l}\text { Results of injection flow } \\
\text { rate and spray pattern }\end{array}$ & $\begin{array}{l}\text { Results of injection spray } \\
\text { length }\end{array}$ \\
\hline Increase spray cone angle & Smaller cone angles \\
\hline Reduction of flow rate & Lower fuel mass flow rate \\
\hline
\end{tabular}

\section{A. Detection Methods}

Recently, there has been renewed interest in detecting EMK, research has been made toward the conditions. In modern automobile industries, electronics part and controller are used the replaced previous mechanical systems by replacing contact points, distributer unit and camshafts. Sensors are ready to be used in order to EMK in closed loop engine[12]. Table 3 shows research done by selecting different type of engines and sensor to detect EMK. Most research are using an algorithm and signals to identify signals of EMK.

Table 3. List of EMK research.

\begin{tabular}{|c|c|c|}
\hline Authors & $\begin{array}{l}\text { Engine } \\
\text { type/detection }\end{array}$ & $\begin{array}{l}\text { Findings/Technics/ } \\
\text { Methods }\end{array}$ \\
\hline $\begin{array}{l}\text { Kiencke } \\
(1999)[13]\end{array}$ & $\begin{array}{l}\text { Four cylinder/ } \\
\text { misfire }\end{array}$ & $\begin{array}{l}\text { Magneto sensor and } \\
\text { the use of a Kalman } \\
\text { filter-based } \\
\text { algorithm }\end{array}$ \\
\hline $\begin{array}{l}\text { Wang et al. } \\
(2005)[14]\end{array}$ & $\begin{array}{l}\text { Four cylinder/ } \\
\text { misfire }\end{array}$ & $\begin{array}{l}\text { Crankshaft and cam } \\
\text { shaft position } \\
\text { sensor, sliding mode } \\
\text { observers }\end{array}$ \\
\hline $\begin{array}{l}\text { Tinaut et al. } \\
(2007)[15]\end{array}$ & $\begin{array}{l}\text { Four cylinder / } \\
\text { misfire }\end{array}$ & $\begin{array}{l}\text { By manipulating all } \\
\text { sensor ready by the } \\
\text { engine, certain data } \\
\text { is used to lead the } \\
\text { EMK detection }\end{array}$ \\
\hline $\begin{array}{l}\text { Devasenapati } \\
\text { et al. } \\
(2010)[16]\end{array}$ & $\begin{array}{l}\text { Four cylinder / } \\
\text { misfire }\end{array}$ & $\begin{array}{l}\text { Accelerometers } \\
\text { analyst by digital } \\
\text { signal process }\end{array}$ \\
\hline $\begin{array}{l}\text { Merola et } \\
\text { al.(2013)[17] }\end{array}$ & $\begin{array}{l}\text { Four cylinder / } \\
\text { knocking }\end{array}$ & $\begin{array}{l}\text { UV-visible natural } \\
\text { emission } \\
\text { spectroscopy }\end{array}$ \\
\hline $\begin{array}{l}\text { Shu et al. } \\
(2013)[18]\end{array}$ & $\begin{array}{l}\text { Single cylinder / } \\
\text { knocking }\end{array}$ & Pressure sensor \\
\hline $\begin{array}{l}\text { Robert et al. } \\
(2015)[19]\end{array}$ & $\begin{array}{l}\text { Single cylinder / } \\
\text { knocking }\end{array}$ & $\begin{array}{l}\text { Large } \quad \text { Eddy } \\
\text { Simulation (LES) }\end{array}$ \\
\hline Zhou et al. & Four cylinder & Applied three \\
\hline
\end{tabular}

\begin{tabular}{|l|l|l|}
\hline (2015)[20] & knocking & $\begin{array}{l}\text { dimensional CFD- } \\
\text { chemistry models }\end{array}$ \\
\hline $\begin{array}{l}\text { Zaim et al. } \\
(2016)[3]\end{array}$ & $\begin{array}{l}\text { Single cylinder/ } \\
\text { misfire }\end{array}$ & $\begin{array}{l}\text { Oxygen sensor } \\
\text { analyst by digital } \\
\text { signal process }\end{array}$ \\
\hline $\begin{array}{l}\text { Dayong et al. } \\
(2016) \text { [21] }\end{array}$ & $\begin{array}{l}\text { Six cylinder / } \\
\text { misfire }\end{array}$ & $\begin{array}{l}\text { suggested the used } \\
\text { of an acoustic } \\
\text { sensor to an engine } \\
\text { could determine the } \\
\text { EMK condition }\end{array}$ \\
\hline $\begin{array}{l}\text { Jung et al. } \\
(2016)[22]\end{array}$ & $\begin{array}{l}\text { Six cylinder / } \\
\text { misfire }\end{array}$ & $\begin{array}{l}\text { Flywheel angular } \\
\text { velocity signals. }\end{array}$ \\
\hline
\end{tabular}

\section{III.METHODOLOGY}

Crankshaft position sensor (CPS)is the part where the signals will actuate spark plug ignition. Rotation of the crankshaft will produce the ignition timing. Therefore, from the CPS signals is used to design a controller for the engine. It will provide signals for ignition timing, engine misfire and knocking condition to be activated.

Signals are recorded from sensors contain noise. It could be avoided by filtering process. Their type of filtering, either analogue or digital filter [3]. Artificial misfire condition is used to control the injector. Signals are recorded from knocking sensor. The knocking sensor was placed on cylinder block, nearest position to the piston..

Figure 1 show project flowchart. The engine are being studied to design the artificial misfire controller. Furthermore, signal processing are studied to get the preferred signals for misfire identification. Signals are filter by MATLAB program. The peak of signals will be analysed.

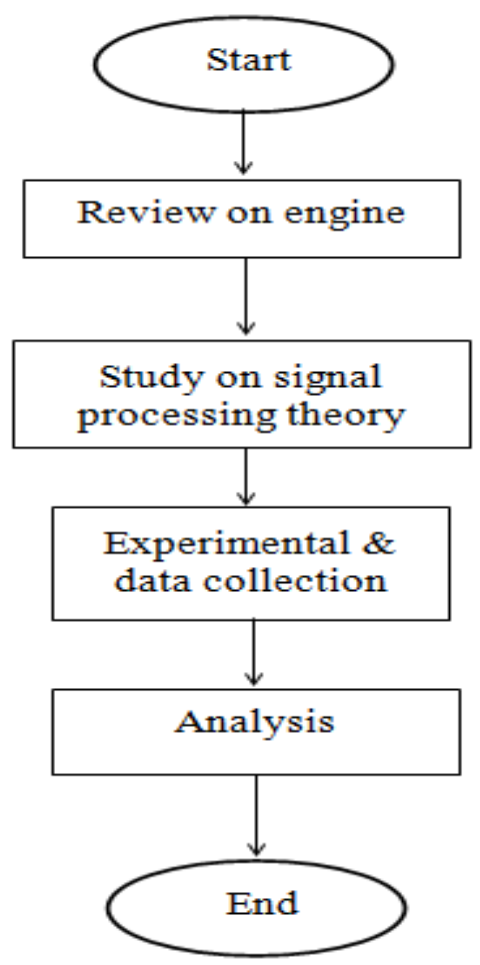

Figure 1: Project Flowchart

Published By: Blue Eyes Intelligence Engineering \& Sciences Publication 
Signal is extracted from the oxygen sensor. During the engine running, combustion flow through the exhaust. Therefore, the oxygen sensor will indicate the amount from the combustion. By using an oscilloscope (Instrustar Electronic), connected to the sensor, the signal will be recorder by the PC. The oscilloscope is link by USB cable to the PC. Multi VirAnalyzer is the software develop by Instrustar Electronic to collect the signal and to be recorded.

\section{RESULT}

An initial test being made for the ignition spark length. It was tested by five(5) sample to identify the length which it is to ignite the fuel air ratio in the cylinder.

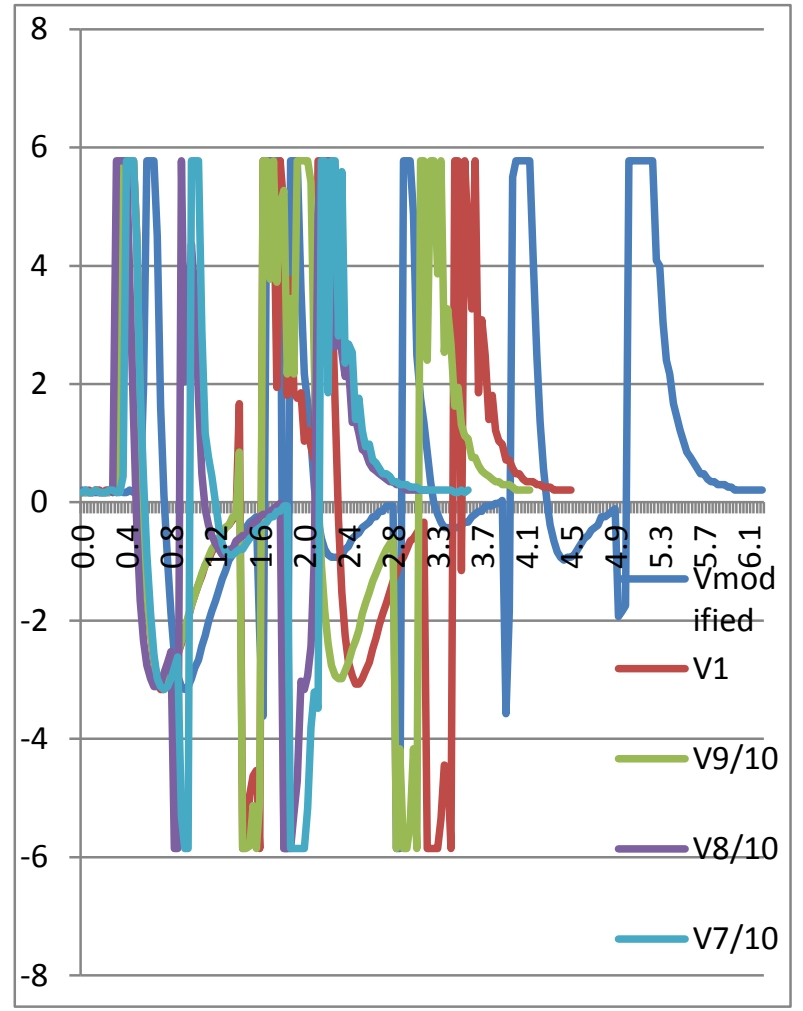

Figure 2,: Spark ignition length in millisecond.

Figure 2 show the data collected. The data varies 3 millisecond to 6.1 millisecond and the voltage of $-6 \mathrm{~V}$ to $6 \mathrm{~V}$ constantly. A program is used to make the different length of the ignition spark.

Data collected from the engine to identify signal from knocking sensor. The raw data are shown below. Figure 3(a) show signals at the engine speed of $1000 \mathrm{rpm}$ idling speed. Two red dash illustrated the misfire condition detected. Figure 3(b) show the signal of engine speed on high speed of $2000 \mathrm{rpm}$. Two red dashes illustrated the misfire condition detected in higher speed range of 3000rpm. Figure 3(c) signal range between 1000-3000 rpm.

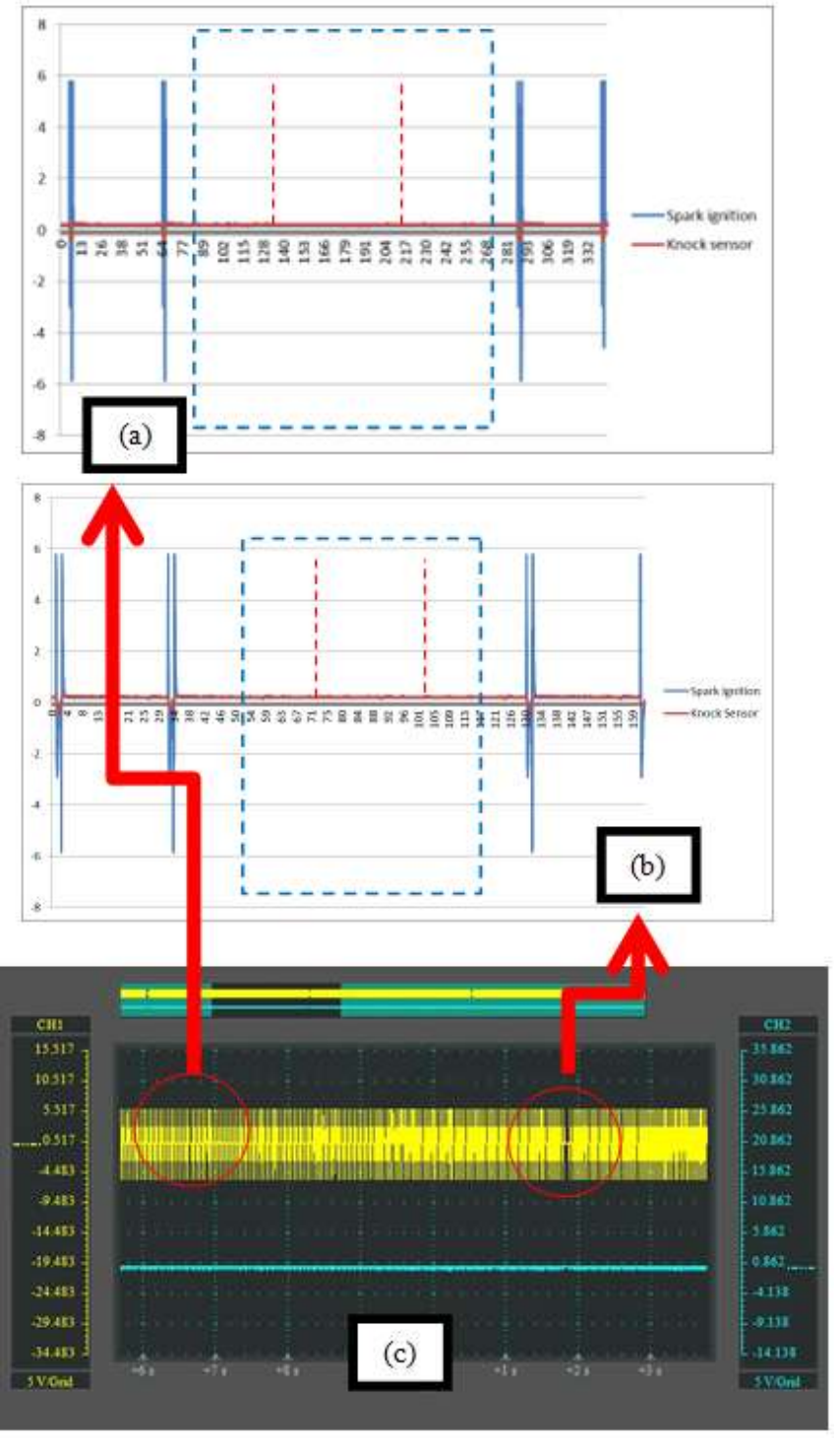

Figure 3,: (a) low speed; (b) high speed; (c) signals range 1000-3000 RPM

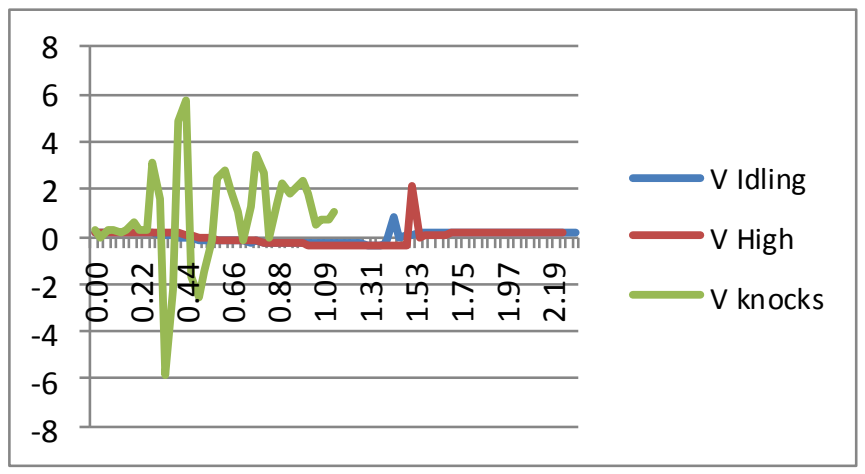

Figure 4 Knocking conditions detected by knocking sensor. 
Figure 4, comparing the data where the vibration signals are analysed with DAQ Instrustar. The signals show peak of each condition. V knocks has the highest peak about $6 \mathrm{~V}$. V idling has the lowest peak of $1 \mathrm{~V}$. The difference are about the knocking condition, wether it is low or high It has been demonstrated that sensors and accelerometers provide signals and frequencies to detect EMK. There is evidence that DAQ plays a crucial role in recording data from analogue to digital [3].

\section{CONCLUSION}

In this study of EMK, vibration result from accelerometer to identify misfire and knocking condition The accelerometer is responsive to engine speed and vibration. The controller will actuate misfire conditions with 10 second interval in each test perform where else engine knocking are based on spark timing angle. On the other hand, it enhances the idle condition of the controller in different engine speed. The reason of EMK detection is to identify the angular ignition timing and engine speed responds to the controller being used. For further study, the signal will be analyse by signal processing to identify the different each signal recorded.

\section{ACKNOWLEDGMENT}

The authors would like to thanks the Ministry of Higher Education, Malaysia for the financial support of this research through Hadiah Latihan Persekutuan (HLP), Kementerian Pengajian Tinggi Malaysia, Innovative System and Instrumentation(ISI) Research Team, School of Aerospace Engineering, Engineering Campus, Universiti Sains Malaysia and Jabatan Pengurusan Politeknik, Kementerian Pengajian Tinggi Malaysia for support of this work.

\section{REFERENCES}

1. J. Merkisz, P. Bogus, and R. Grzeszczyk, "Overview of engine misfire detection methods used in on board diagnostics," J. Kones, Combust. Engines, vol. 8, no. 1-2, pp. 326-341, 2001.

2. T. X. Xd and D. R. D. X. X, "Knocking combustion in spark-ignition engines," Prog. Energy Combust. Sci., vol. 61, pp. 78-112, 2017.

3. M. Z. M. Pauzi, E. A. Bakar, and M. F. Ismail, "Feature Identification and Filtering for Engine Misfire Detection (EMD) Using Zirconia Oxygen Sensor," IOP Conf. Ser. Mater. Sci. Eng., vol. 114, p. 12140, 2016.

4. Q. he Luo and B. gang Sun, "Inducing factors and frequency of combustion knock in hydrogen internal combustion engines," Int. J. Hydrogen Energy, vol. 41, no. 36, pp. 16296-16305, 2016.

5. S. Szwaja, K. R. Bhandary, and J. D. Naber, "Comparisons of hydrogen and gasoline combustion knock in a spark ignition engine," Int. J. Hydrogen Energy, vol. 32, no. 18, pp. 5076-5087, 2007.

6. M. Reyes, F. V. Tinaut, A. Melgar, and A. Pérez, "Characterization of the combustion process and cycle-to-cycle variations in a spark ignition engine fuelled with natural gas/hydrogen mixtures," Int. J. Hydrogen Energy, vol. 41, no. 3, pp. 2064-2074, 2016.

7. E. Galloni, "Knock-limited spark angle setting by means of statistical or dynamic pressure based methods," Energy Convers. Manag., vol. 116, pp. 11-17, 2016.
8. J. Zareei and A. H. Kakaee, "Study and the effects of ignition timing on gasoline engine performance and emissions," Eur. Transp. Res. Rev., vol. 5, no. 2, pp. 109-116, 2013.

9. H. Song, J. Xiao, Y. Chen, and Z. Huang, "The effects of deposits on spray behaviors of a gasoline direct injector," Fuel, vol. 180, pp. 506-513, 2016.

10. B. Wang, T. Badawy, Y. Jiang, H. Xu, A. Ghafourian, and $\mathrm{X}$. Zhang, "Investigation of deposit effect on multi-hole injector spray characteristics and air / fuel mixing process," Fuel, vol. 191, pp. 10-24, 2017.

11.P. Brequigny, F. Halter, C. Mounaïm-rousselle, and T. Dubois, "Fuel performances in Spark-Ignition ( SI ) engines: Impact of flame stretch," vol. 166, pp. 98-112, 2016.

12.W. J. Fleming, "Overview of Automotive Sensors," IEEE Sens. J., vol. 1, no. 4, pp. 296-308, 2001.

13. U. Kiencke, "Engine misfire detection," Control Eng. Pract., vol. 7, no. 2, pp. 203-208, 1999.

14. Y. Wang and F. Chu, "Real-time misfire detection via sliding mode observer," Mech. Syst. Signal Process., vol. 19, no. 4, pp. 900-912, 2005.

15 .F. V. Tinaut, A. Melgar, H. Laget, and J. I. Domínguez, "Misfire and compression fault detection through the energy model," Mech. Syst. Signal Process., vol. 21, no. 3, pp. 1521-1535, 2007.

16.S. B. Devasenapati, V. Sugumaran, and K. I. Ramachandran, "Misfire identification in a four-stroke four-cylinder petrol engine using decision tree," Expert Syst. Appl., vol. 37, no. 3, pp. 2150-2160, 2010.

17. S. S. Merola, G. Valentino, C. Tornatore, and L. Marchitto, "In-cylinder spectroscopic measurements of knocking combustion inaSI engine fuelled with butanol-gasoline blend," Energy, vol. 62, pp. 150-161, 2013.

18. G. Shu, J. Pan, and H. Wei, "Analysis of onset and severity of knock in SI engine based on in-cylinder pressure oscillations," Appl. Therm. Eng., vol. 51, no. 1-2, pp. 1297-1306, 2013.

19. A. Robert, S. Richard, O. Colin, L. Martinez, and L. De Francqueville, "LES prediction and analysis of knocking combustion in a spark ignition engine," Proc. Combust. Inst., vol. 35, no. 3, pp. 2941-2948, 2015.

20. D. Z. Zhou, W. M. Yang, H. An, and J. Li, "Application of CFD-chemical kinetics approach in detecting RCCI engine knocking fuelled with biodiesel/methanol," Appl. Energy, vol. 145, pp. 255-264, 2015.

21. N. Dayong, S. Changle, G. Yongjun, Z. Zengmeng, and H. Jiaoyi, "Extraction of fault component from abnormal sound in diesel engines using acoustic signals," Mech. Syst. Signal Process., vol. 75, pp. 544-555, 2016.

22. D. Jung, E. Frisk, and M. Krysander, "A flywheel error compensation algorithm for engine misfire detection," Control Eng. Pract., vol. 47, pp. 37-47, 2016. 